\title{
Ice nucleation by water-soluble macromolecules
}

\author{
B. G. Pummer ${ }^{1}$, C. Budke ${ }^{2}$, S. Augustin-Bauditz ${ }^{3}$, D. Niedermeier ${ }^{3,4}$, L. Felgitsch ${ }^{5}$, C. J. Kampf ${ }^{1}$, R. G. Huber ${ }^{6}$, \\ K. R. Liedl ${ }^{6}$, T. Loerting ${ }^{7}$, T. Moschen ${ }^{8}$, M. Schauperl ${ }^{6}$, M. Tollinger ${ }^{8}$, C. E. Morris ${ }^{9}$, H. Wex ${ }^{3}$, H. Grothe ${ }^{5}$, U. Pöschl ${ }^{1}$, \\ T. Koop ${ }^{2}$, and J. Fröhlich-Nowoisky ${ }^{1}$ \\ ${ }^{1}$ Dept. Multiphase Chemistry, Max Planck Institute for Chemistry, Hahn-Meitner-Weg 1, 55128 Mainz, Germany \\ ${ }^{2}$ Faculty of Chemistry, Bielefeld University, Universitätsstraße 25, 33615 Bielefeld, Germany \\ ${ }^{3}$ Experimental Aerosol and Cloud Microphysics Dept., Leibniz Institute of Tropospheric Research, \\ Permoserstraße 15, 04318 Leipzig, Germany \\ ${ }^{4}$ Dept. of Physics, Michigan Technological University, 1400 Townsend Drive, 49931 Houghton, Michigan, USA \\ ${ }^{5}$ Inst. for Materials Chemistry, Vienna University of Technology, Getreidemarkt 9, 1060 Vienna, Austria \\ ${ }^{6}$ Inst. for General, Inorganic and Theoretical Chemistry, University of Innsbruck, Innrain 80-82, 6020 Innsbruck, Austria \\ ${ }^{7}$ Inst. for Physical Chemistry, University of Innsbruck, Innrain 80-82, 6020 Innsbruck, Austria \\ ${ }^{8}$ Inst. for Organic Chemistry, Center for Molecular Biosciences Innsbruck, University of Innsbruck, \\ Innrain 80-82, 6020 Innsbruck, Austria \\ ${ }^{9}$ UR0407 Pathologie Végétale, Institut National de la Recherche Agronomique, 84143 Montfavex CEDEX, France
}

Correspondence to: B. G. Pummer (b.pummer@mpic.de)

Received: 26 August 2014 - Published in Atmos. Chem. Phys. Discuss.: 19 September 2014

Revised: 23 March 2015 - Accepted: 29 March 2015 - Published: 21 April 2015

\begin{abstract}
Cloud glaciation is critically important for the global radiation budget (albedo) and for initiation of precipitation. But the freezing of pure water droplets requires cooling to temperatures as low as $235 \mathrm{~K}$. Freezing at higher temperatures requires the presence of an ice nucleator, which serves as a template for arranging water molecules in an ice-like manner. It is often assumed that these ice nucleators have to be insoluble particles. We point out that also free macromolecules which are dissolved in water can efficiently induce ice nucleation: the size of such ice nucleating macromolecules (INMs) is in the range of nanometers, corresponding to the size of the critical ice embryo. As the latter is temperature-dependent, we see a correlation between the size of INMs and the ice nucleation temperature as predicted by classical nucleation theory. Different types of INMs have been found in a wide range of biological species and comprise a variety of chemical structures including proteins, saccharides, and lipids. Our investigation of the fungal species Acremonium implicatum, Isaria farinosa, and Mortierella alpina shows that their ice nucleation activity is caused by proteinaceous water-soluble INMs. We combine these new results and literature data on INMs from fungi, bacteria, and pollen with theoretical calculations to develop a chemical in-
\end{abstract}

terpretation of ice nucleation and water-soluble INMs. This has atmospheric implications since many of these INMs can be released by fragmentation of the carrier cell and subsequently may be distributed independently. Up to now, this process has not been accounted for in atmospheric models.

\section{Introduction}

Although ice is thermodynamically favored over liquid water at temperatures below $273.15 \mathrm{~K}$, the phase transition is kinetically hindered. Consequently, supercooled droplets of ultrapure water stay liquid until temperatures as low as $235 \mathrm{~K}$ are reached. The spontaneous self-assembling of water molecules in an ice-like arrangement, which is necessary for freezing to occur, is called homogeneous ice nucleation (Fig. 1a). At higher temperatures, catalytic surfaces which act as an ice-mimicking template are necessary. The process, in which water molecules are stabilized in an ice-like arrangement by an impurity, is called heterogeneous ice nucleation (Fig. 1b, c). An impurity that possesses this ability is called an ice nucleator (IN), or sometimes an ice nucleus. The driving force that causes ice nucleation activity (INA) 

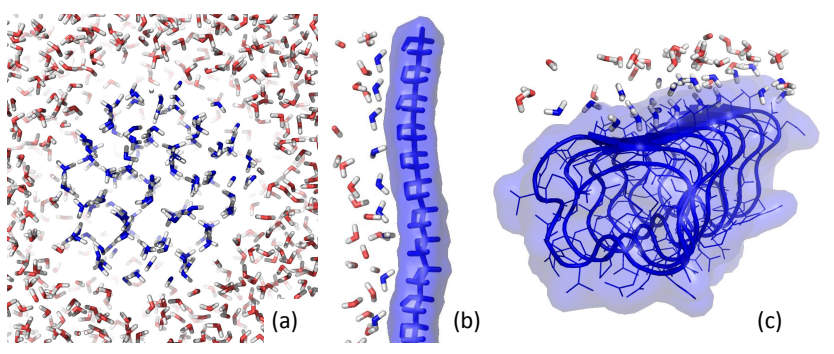

Figure 1. Visualization of water molecule ordering based on molecular model calculations (Sect. S2.1): homogeneous ice nucleation (a); heterogeneous ice nucleation by ordering of water molecules on a polyvinyl alcohol (PVA) strain, which is a 1-D template (b), and an antifreeze protein that has a similar sequence and structure as the bacterial INMs, which is a 2-D template (c). Each image contains water molecules that are ordered (blue) and some randomly distributed water molecules (red).

is the interaction between the partial charges on the $\mathrm{H}$ and $\mathrm{O}$ atoms in the water molecules and the properly arranged (partial) charges on the IN surface. Therefore, the IN has to carry functional groups at the proper position to be effective (Liou et al., 2000; Zachariassen and Kristiansen, 2000). In most cases it is not the whole surface of an IN that participates in ice nucleation, but only certain sections, which are known as "active sites" (Edwards et al., 1962; Katz, 1962).

The larger the active site of an IN is and the better the functional groups it carries fit the ice lattice, the more effective it stabilizes ice clusters, and so the higher the freezing temperature. Consequently, single molecules with a low molar mass are not well suited to nucleate ice. In fact, soluble compounds consisting of ions, such as salts, or very small molecules, such as sugars and short-chained alcohols, cause a depression of the thermodynamic freezing point and the homogeneous ice nucleation temperature (Koop, 2004). However, if single molecules are so large that they allocate a large enough active surface, they can become INs by themselves. Such ice nucleating macromolecules (INMs) are especially common among biological INs. More information about INMs is given in Sect. S1.1 in the Supplement. For the same reason, some compounds with low molar mass which show no INA in solution can act as INs if they are crystallized in layers of a certain arrangement (Fukuta, 1966). Further information related to the ice nucleation process is compiled in the Supplement (Sects. S1.2, S1.3, and S1.4). INA has been discovered in various forms of life, including certain bacteria, fungi, algae, plants, and animals. Studies for characterizing the active sites of some of these organisms have revealed that they are biopolymers in almost all cases examined. The chemistry of these INMs is as diverse as the range of species they represent (Table 1, Sect. 4.1): overall, proteins, higher saccharides and lipids, and hybrid compounds can play a role in INA, both as singular molecules as well as in aggregated form. They occur in several species of bacteria, fungi, plants, and animals. Apart from being INMs, they are very diverse in their properties, like size or heat tolerance, as their diverse chemical nature suggests.

In this study, we chemically characterize the water-soluble INMs found in the fungal species Acremonium implicatum and Isaria farinosa and we compare the results with other recent studies of water-soluble INMs from the fungus Mortierella alpina (Fröhlich-Nowoisky et al., 2015), from birch pollen (Pummer et al., 2012; Augustin et al., 2013), and from bacteria (Niedermeier et al., 2014). We also discuss relevant key findings of related earlier studies on the INA of biological materials (e.g., Govindarajan and Lindow, 1988a). Combining these data with calculations derived from classical nucleation theory (Zobrist et al., 2007), we draw conclusions about the nature, sources, and potential atmospheric effects of biological INMs.

\section{Methods}

\subsection{Characterization of new fungal INMs}

The fungi A. implicatum and I. farinosa were cultivated on plates of potato dextrose agar $\left(\mathrm{VWR}^{\mathrm{TM}}\right)$, incubated at ambient temperature for 1-2 weeks, until the first mycelium was formed, and then left to grow at $\sim 280 \mathrm{~K}$ for $2-3$ months (A. implicatum) or 6-10 months (I. farinosa). The mycelium was scratched off with either a scalpel or an inoculating loop and put into a $15 \mathrm{~mL}$ Falcon tube. High-purity water $(18.2 \mathrm{M} \Omega \times \mathrm{cm})$ was drawn from a water purification system (Thermo Scientific ${ }^{\mathrm{TM}}$ Barnstead GenPure XCAD plus), autoclaved at $394 \mathrm{~K}$ for $20 \mathrm{~min}$, and filtrated through a sterile $0.1 \mu \mathrm{m}$ PES filter $\left(\right.$ Corning $^{\mathrm{TM}}$ ). Then, $10 \mathrm{~mL}$ of the highpurity water was added to the mycelium in the tube, which was then shaken with a vortex device $\left(\mathrm{VWR}^{\mathrm{TM}}\right.$ lab dancer) three times for 30 seconds and filtrated through a $5 \mu \mathrm{m}$ PES syringe filter $\left(\operatorname{Acrodisc}^{\circledR}\right)$, yielding a transparent solution. A small aliquot of the $5 \mu \mathrm{m}$ filtrate was branched off for INA measurement as described later in this section, while the rest was further filtrated through a $0.1 \mu \mathrm{m}$ PES syringe filter (Acrodisc ${ }^{\circledR}$ ). A small aliquot of the $0.1 \mu \mathrm{m}$ filtrate was saved for INA tests. Further aliquots were exposed to different procedures, which are listed below, and then tested for changes in their INA. This provides information about the chemistry of the INMs. In all cases, not only the filtrates but also pure water samples which were treated the same way were tested as a negative reference.

- Filtration through size exclusion filtration tubes (Vivaspin ${ }^{\circledR} 500$ ) with a cutoff of 300 and $100 \mathrm{kDa}$. The passage through a filter indicates that the molecules are smaller than the given cutoff.

- Exposure to heat for $1 \mathrm{~h}: 308$ and $333 \mathrm{~K}$, providing information about thermal stability. 
Table 1. Chemical properties of some INs. $T_{\mathrm{dn}}$ shows the temperature above which they are denatured. A question mark indicates uncertainty. See Sect. 4.1 for the sources of these data. $\theta\left[^{\circ}\right] \pm \sigma\left[^{\circ}\right]$ are the calculated contact angle distribution according to the soccer ball model.

\begin{tabular}{|c|c|c|c|c|c|c|c|c|}
\hline Type & Organism & Cell-free & Protein & Saccharide & Lipid & $T_{\mathrm{dn}}$ & size (1 unit) & $\theta\left(^{\circ}\right) \pm \sigma\left(^{\circ}\right)$ \\
\hline \multirow{2}{*}{ BINMs } & P. syringae & - & + & + & + & $<313 \mathrm{~K}$ & $150-180 \mathrm{kDa}$ & \multirow[t]{2}{*}{$34.1 \pm 2.3$} \\
\hline & E. herbicola & + & + & + & + & $<313 \mathrm{~K}$ & $150-180 \mathrm{kDa}$ & \\
\hline \multirow{6}{*}{ Fungal INs } & R. chrysoleuca & + & + & - & - & $>333 \mathrm{~K}$ & $<0.22 \mu \mathrm{m}$ & \multirow{6}{*}{$\begin{array}{l}33.2 \pm 2.3 \\
24.6 \pm 0.6 \\
26.4 \pm 1.1\end{array}$} \\
\hline & F. avenaceum & + & + & - & - & $>333 \mathrm{~K}$ & $<0.22 \mu \mathrm{m}$ & \\
\hline & A. implicatum & + & + & $-?$ & + & $308-333 \mathrm{~K}$ & $100-300 \mathrm{kDa}$ & \\
\hline & I. farinosa & + & + & $-?$ & - & $308-333 \mathrm{~K}$ & $\sim 300 \mathrm{kDa}$ & \\
\hline & M. alpina & + & + & $-?$ & - & $333-371 \mathrm{~K}$ & $100-300 \mathrm{kDa}$ & \\
\hline & rust spores & $? ?$ & $? ?$ & + & $? ?$ & $\sim 373 \mathrm{~K}$ & $? ?$ & \\
\hline \multirow{4}{*}{ Animal INs } & Tipula & + & + & $+?$ & + & $? ?$ & $800 \mathrm{kDa}$ & \\
\hline & Dendroides & + & + & $-?$ & $+/-$ & $? ?$ & $>70 \mathrm{kDa}$ & \\
\hline & Vespula & + & + & - & $? ?$ & $<373 \mathrm{~K}$ & $74 \mathrm{kDa}$ & \\
\hline & Eurosta* & + & - & - & - & $? ?$ & $>100 \mu \mathrm{m}$ & \\
\hline \multirow{6}{*}{ Plant INs } & Secale leaves & $? ?$ & + & + & + & $<363 \mathrm{~K}$ & $? ?$ & \multirow{6}{*}{$58.2 \pm 4.6$} \\
\hline & Prunus wood & - & - & $? ?$ & $? ?$ & $313-323 \mathrm{~K}$ & $? ?$ & \\
\hline & Betula pollen & + & - & + & - & $445-460 \mathrm{~K}$ & $100-300 \mathrm{kDa}$ & \\
\hline & Lobelia fluid & + & - & $+?$ & - & $>373 \mathrm{~K}$ & $? ?$ & \\
\hline & Opuntia fluid & + & - & + & - & $? ?$ & $<70 \mu \mathrm{m}$ & \\
\hline & different algae & $? ?$ & $? ?$ & $? ?$ & $? ?$ & $? ?$ & $? ?$ & \\
\hline
\end{tabular}

* Only the calcium phosphate spherules are regarded here, not the fat cells.

- Addition of $6.0 \mathrm{M}$ guanidinium chloride (Promega ${ }^{\circledR}$ ), which is a chaotropic reagent used for protein denaturation.

- Addition of 0.3 M boric acid (National Diagnostics ${ }^{\circledR}$ ), which esterifies with saccharide $\mathrm{OH}$ groups and thereby blocks the site.

- Digestion with enzymes (Applichem ${ }^{\circledR}$ ) for at a given incubation temperature: lipase for $1 \mathrm{~h}$ at $308 \mathrm{~K}$ for fat digestion, papain for $5 \mathrm{~h}$ at $296 \mathrm{~K}$ for protein digestion. For the latter, two more temperatures were investigated ( $5 \mathrm{~h}$ at $308 \mathrm{~K}, 1 \mathrm{~h}$ at $333 \mathrm{~K}$ ) since its optimum temperature is about $338 \mathrm{~K}$, but the investigated INMs turned out to be rather thermolabile. Conveniently, papain still functions at temperatures far lower than its optimum, but with lower reaction rates. In our case, the lowest investigated temperature was sufficient.

To determine the IN concentration per gram of mycelium, the same setup and procedure as in Fröhlich-Nowoisky et al. (2015) were applied: each sample was diluted with ultrapure water to an INM concentration where Eq. (1) gives finite results (the proper dilution was determined by trial and error). Then, $50 \mu \mathrm{L}$ aliquots of the dilute were pipetted into 24-32 wells of a 96-well PCR tray $\left(\operatorname{Axon}^{\mathrm{TM}}{ }^{\mathrm{M}}\right.$ ), which was sealed with adhesive foil. The plate was inserted into an isolated PCR-plate thermal block, which was tempered

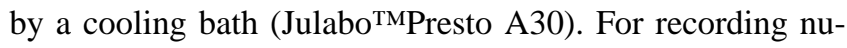
cleation spectrums, the block was cooled to an initial tem- perature of 269.15 or $270.15 \mathrm{~K}$. Then, the block was further cooled in 0.5 to $2 \mathrm{~K}$ steps each $12 \mathrm{~min}$. After each step, the number of frozen droplets was counted. They can be distinguished from liquid droplets since they reflect incident light differently, and therefore appear much darker. We calculated the IN concentration (number of INs per grams of mycelium) using a variant of the Vali formula (Eq. 1) (Vali, 1971):

$n_{\mathrm{m}}\left[g^{-1}\right]=-\ln \left(1-f_{\text {ice }}\right) \times \frac{V_{\text {wash }}}{V_{\text {drop }}} \times \frac{F_{\text {dil }}}{m_{\text {myc }}}$.

$n_{\mathrm{m}}$ is the number of INMs per gram of mycelium, $f_{\text {ice }}$ the fraction of frozen droplets, $V_{\text {wash }}$ the volume of water added for washing $\left(10 \mathrm{~mL}\right.$ in this study), $V_{\text {drop }}$ the droplet volume in the freezing assay $\left(0.05 \mathrm{~mL}\right.$ in this study), $F_{\text {dil }}$ the dilution factor of the extract, and $m_{\text {myc }}$ the mass of the mycelium. For the formula to work, a proper dilution, where $0<f_{\text {ice }}<1$ is fulfilled, is necessary. In the case of $f_{\text {ice }}=0$, the dilution is too high, and the formula gives $n_{\mathrm{m}}=0$ as a result. In the case of $f_{\text {ice }}=1$, the sample is too concentrated since $n_{\mathrm{m}}$ becomes infinite. We note that Eq. (1) assumes that each droplet contains the same number of IN, i.e., the mean number of IN. However, at very small concentrations, the distribution of INMs in the droplets follows Poisson statistics, so that even for a mean number of one INM per droplet, some droplets may contain two or more INMs, and others no INMs at all. Without the use of Poisson statistics all of these would be counted as one in the analysis (Augustin et al., 2013). 
To quantify the efficacy of the new-found INMs of A. implicatum and I. farinosa in comparison with others, we used the soccer ball model (SBM; Niedermeier et al., 2011, 2014), which combines classical nucleation theory with the assumption of a contact angle distribution to calculate mean contact angles $\theta$ and standard deviations $\sigma$ from the $0.1 \mu \mathrm{m}$ filtrate curves. This is done by determining values for $\theta$ and $\sigma$ such that the measured values of $f_{\text {ice }}$ are reproduced by the model. The corresponding equation describing the contact angle distribution and the SBM are given explicitly in Niedermeier et al. (2014). Using a mass-to-size conversion table for proteins from Erickson (2009), we estimated the diameter of our INMs to be about $4 \mathrm{~nm}$, which was used for the SBM parameterization. In comparison, we also calculated mean $\theta$ and $\sigma$ of $M$. alpina from comparable filtrates (Fröhlich-Nowoisky et al., 2015), and added literature data for INMs from birch pollen (Augustin et al., 2013) and bacteria (Niedermeier et al., 2014). The concept of contact angles has, in the past, been applied for ice nucleating particles consisting of mineral dust, for which reasonable results were obtained (e.g., Marcolli et al., 2007; Welti et al., 2012). Here we apply it to describe the ice nucleation induced by watersoluble INMs, and we were able to derive contact angle distributions such that all measured data can be reproduced by the SBM. More specifically, a contact angle distribution determined for a sample reproduced all measurements done for that sample, even if different concentrations, different cooling times or completely different measurement approaches, as those described in the following paragraphs, were used.

INA was also measured with two additional experimental techniques. For both setups, $0.1 \mu \mathrm{m}$ filtrates that were prepared as described at the top of this section were diluted and applied. These two additional methods were included to expand the data to lower temperatures, which was possible due to the smaller droplet sizes these methods examined (Bielefeld Ice Nucleation ARraY (BINARY) droplet volumes are about $1 \mu \mathrm{L}$ ) and to ensure that possible interactions between the examined droplets and the substrates did not influence the results (Leipzig Aerosol Cloud Interaction Simulator (LACIS) examined freely floating droplets). Resulting values for $n_{\mathrm{m}}$ are compared to the $n_{\mathrm{m}}$ derived from the conventional freezing droplet array. Those systems are

(i) A droplet freezing array termed BINARY, which consists of a $6 \times 6$ array of microliter droplets on a hydrophobic glass slide on top of a Peltier cooling stage. A detailed description of the technique, the preparation of droplets, and the data acquisition and evaluation is given in Budke and Koop (2015).

(ii) A vertical flow tube named LACIS, which is described in detail in Hartmann et al. (2011). Basically, droplets are generated from the filtrate and dried. The residual particles are then size-selected, humidified to form uniform droplets and inserted into the tube, where they are cooled to the temperature of interest. The procedure was similar to that for the birch pollen washing waters described in Augustin et al. (2013).

\subsection{Characterization of birch pollen INMs}

To test the hypotheses that birch pollen INMs are polysaccharides and not proteins (Pummer et al., 2012), further procedures for characterization of the birch pollen INMs were carried out. Therefore, birch pollen extracts were prepared by suspending and shaking $10 \mathrm{mg} \mathrm{mL}^{-1}$ pollen in ultrapure water for several hours, and then vacuum filtering the suspension through a $0.1 \mu \mathrm{m}$ PES filter (Corning ${ }^{\mathrm{TM}}$ ). The aqueous fraction was then exposed to different treatments, and $n_{\mathrm{m}}$ was determined the same way as for the fungi, with 24 or 32 droplets per sample, at 258 or $256 \mathrm{~K}$. In all cases, reference samples without addition of the reagents were measured and defined as $100 \%$ INA. The results are listed in Table 2.

First, boric acid was added to an aliquot of fungal extract to a concentration of $0.75 \mathrm{M}$. The aliquot was left overnight at room temperature, as boric acid is known to esterify with sugars. This treatment should alter the INA of the birch pollen INMs, in case that saccharides play a role. However, since the esterification process does not necessarily affect all functional groups, the INA might be only partially eliminated. Since the INA assay preparation has a certain statistical uncertainty, minor changes in the INA are difficult to interpret. Therefore, we also investigated untreated birch pollen extracts as a reference. The same procedure was repeated by heating aliquots with and without boric acid to $343 \mathrm{~K}$ for $2 \mathrm{~h}$ to accelerate the esterification process.

To check if birch pollen INMs are indeed nonproteinaceous, three separate $100 \mu \mathrm{L}$ aliquots were each mixed with $94 \mu \mathrm{L}$ of (i) water, (ii) medium without enzyme, (iii) medium with Trypsin, and were incubated for $18 \mathrm{~h}$ at $310 \mathrm{~K}$. Additionally, $100 \mu \mathrm{L}$ water was treated like (iii). Trypsin is an enzyme that breaks down proteins, but demands a certain medium. For each sample an INA assay as described in Sect. 2.1 was run.

In addition, aliquots of the birch pollen extracts digested with Trypsin and medium before and after incubation were forwarded through a size exclusion chromatography (SEC) column, and the different eluted fractions were tested for their INA. Details about the setup and the measurements are presented in Sect. S2.2. With SEC, we checked if the enzymatic treatment changed the mass range of the birch pollen INMs.

\subsection{Ice nucleation experiments with bacterial INM peptides}

A sample of the 16-amino acid peptide fragment which is the repetitive element in the bacterial INM (BINM) of Pseudomonas syringae was investigated for its INA. The peptide with the primary sequence GSTQTAGEESSLTAGY was obtained from PSL (Heidelberg, Germany) and purified chromatographically using a HiTrap Desalting column (GE 
Table 2. An overview of the investigation of birch pollen extracts. The percentage is the relative number of INs in comparison to the untreated aliquot at a given temperature $T(\mathrm{~K})$. Lines labeled with "(ref)" refer to reference measurements under the same conditions with pure water instead of extract.

\begin{tabular}{lrr}
\hline Treatment & $\%$ INA & $T(\mathrm{~K})$ \\
\hline None & 100 & both \\
None (ref) & $<9$ & both \\
Boric acid & 15 & 256 \\
Boric acid (ref) & 0 & 256 \\
$343 \mathrm{~K}$ & 29 & 256 \\
$343 \mathrm{~K}+$ boric acid & 3 & 256 \\
Medium & 34 & 258 \\
Medium + Trypsin & 30 & 258 \\
Medium + Trypsin (ref) & 13 & 258 \\
\hline
\end{tabular}

Healthcare) with high-purity water $(18.2 \mathrm{M} \Omega \times \mathrm{cm})$ from a Milli-Q water purification system (Millipore). The yield of pure peptide was determined using a NanoPhotometer $\left(\varepsilon_{0}=1490 \mathrm{M}^{-1} \mathrm{~cm}^{-1}\right)$.

We measured peptide solutions with 10, 20, and $30 \mathrm{mg} \mathrm{mL}^{-1}$ using the oil immersion cryo-microscopic method, which is described in detail in Pummer et al. (2012). As such we prepared emulsions consisting of $45 \%$ wt aqueous peptide solution and $55 \%$ wt oil (paraffin-lanolin). The frozen fractions of droplets with diameters of $20-50 \mu \mathrm{m}$ were documented with the software Minisee ${ }^{\odot}$ as a function of temperature.

\section{Results}

\subsection{Experimental characterization of INMs}

The results of the chemical characterization of the fungal filtrates are composed in Fig. 2. The quantitative passage through the $0.1 \mu \mathrm{m}$ pore size filters, yielding optically transparent, particle-free filtrates, demonstrates that those INMs are cell-free and stay in solution when they are extracted with water.

The initial freezing temperature was $269 \mathrm{~K}$ for I. farinosa and $264 \mathrm{~K}$ for A. implicatum. The calculated contact angles for I. farinosa and M. alpina are the highest, while the one of A. implicatum lies in the range of that of the BINM (Table 1). The reduction of INA by papain and by guanidinium chloride indicates that the INMs of both species are proteinaceous. Lipids seem to play a role in A. implicatum, but none in I. farinosa. Both were resistant against boric acids, making contributions of carbohydrates to the INA unlikely. Both INMs are more heat sensitive than other fungal INMs since they were destroyed at $333 \mathrm{~K}$. A. implicatum has a mass of approximately 100 to $300 \mathrm{kDa}$ since it quantitatively passes through the $300 \mathrm{kDa}$ filter, but not through the $100 \mathrm{kDa}$ filter. About $95 \%$ of I. farinosa INM were retained in the $300 \mathrm{kDa}$ filter in comparison to the $0.1 \mu \mathrm{m}$ filter, and the initial freezing temperature is shifted below $268 \mathrm{~K}$. This suggests that there are larger, more active states of I. farinosa INMs and smaller ones active at lower temperatures.

Figure 3 shows the comparison between the data from BINARY, LACIS, and the droplet freezing array (Sect. 2.1). Each strain shows a relatively good overlap of the plateaus obtained with the different methods. Only when comparing the C-strain measurements can a difference in total $n_{\mathrm{m}}$ be seen, which, however, is less than 1 order of magnitude. The initial freezing temperatures are higher for the conventional droplet freezing array in Mainz in comparison with BINARY. This may indicate that the investigated INMs show a small time-dependence, which would lead to an increase in $n_{\mathrm{m}}$ at lower temperature for the experiment with the larger cooling rate (i.e., BINARY), in agreement with the observations. From that it becomes evident that onset temperatures, which were often reported in the past, do not properly describe the ice nucleation process. They depend on the detection limit of the measurement method, as well as the INM content per droplet, and they are influenced by impurities or statistical outliers. Hence, the temperature at which $50 \%$ of all droplets froze $\left(T_{50}\right)$ was taken for examination. If we assume that the mass of a single INM is about $100 \mathrm{kDa}=1.7 \times 10^{-19}$ grams and that the maximum number density we found was $n_{\mathrm{m}}=10^{10}$ per gram (Fig. 3), the INMs amount to approximately $1.7 \mathrm{ppb}$ of the total mycelium mass.

The results of the birch pollen measurements, which are given in Table 2, suggest that both the medium for the Trypsin test and the boric acid led to a reduction in INA. The addition of Trypsin had no additional effect, which speaks against the proteinaceous nature of those INMs. It is most likely that it is the formic acid from the medium that decreases the INA in the respective measurement since it esterifies with hydroxyls similar to the boric acid. This is consistent with the resistance against other proteases and guanidinium chloride (Pummer et al., 2012), and the lack of the spectroscopic signature typical for proteins in the most active eluates. Overall, we confirm that the birch pollen INMs are not proteins but most likely polysaccharides. After the elution from the SEC column, small amounts of INMs were spread across all fractions of the eluate. This might be caused by the adhesion of the organic matter in the extracts to the column packing, which undermines the separation principle. The tendency for adhesion of organic matter from pollen was investigated by Pummer et al. (2013b). Nevertheless, there was an unambiguous maximum in the 335 to $860 \mathrm{kDa}$ fraction before and after digestion. In parallel, we recorded the absorbance of the eluate at $280 \mathrm{~nm}$ using a UV detector, which is a quite reliable way to detect most proteins. However, the detector showed no signal when the INA maximum was eluted. This alone makes it very unlikely that the birch pollen INMs are proteinaceous. The discrepancy with the mass range stated in Pummer et al. (2012) could be explained by the slightly higher investigation temperatures, which was 

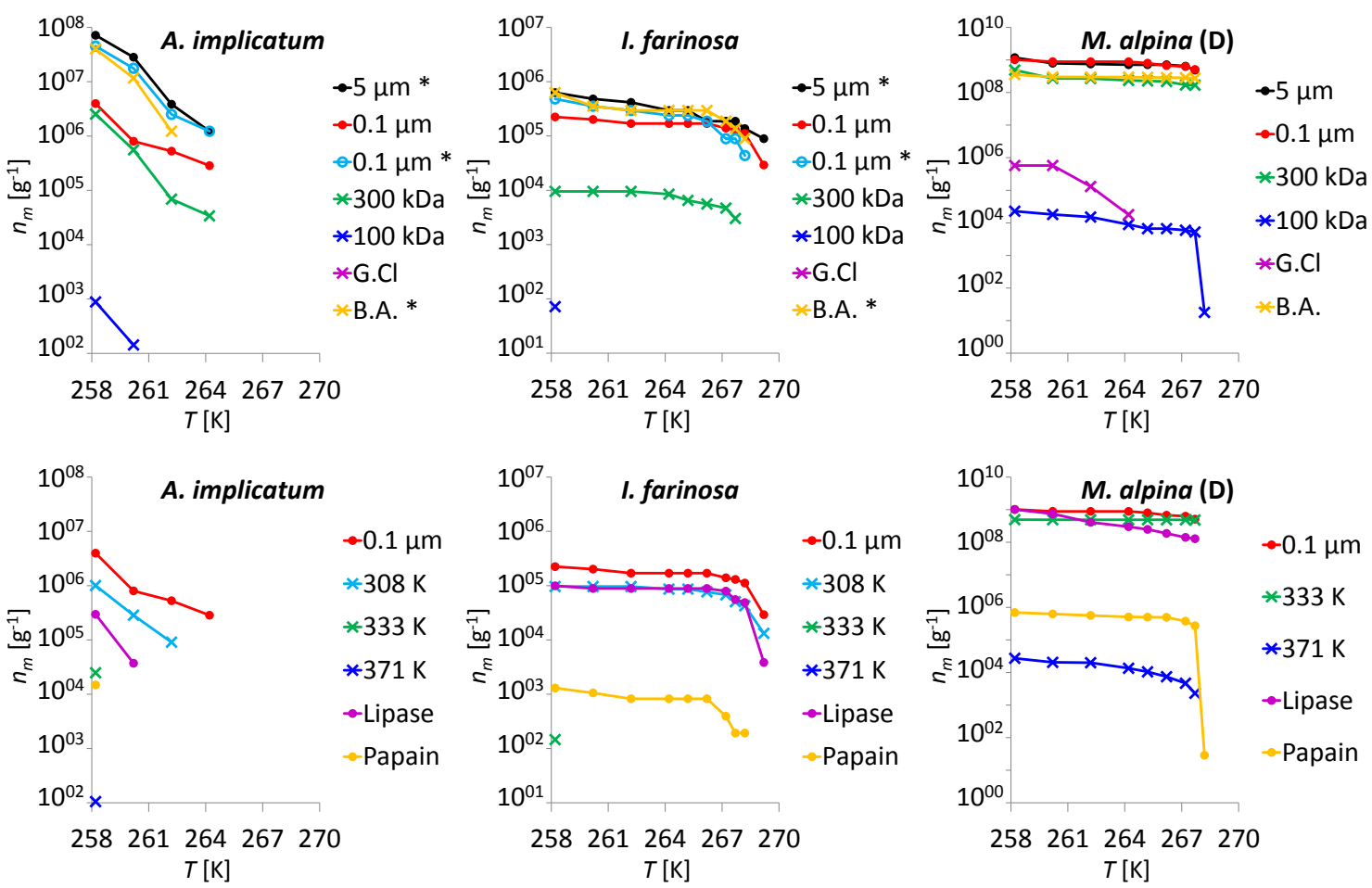

Figure 2. $n_{\mathrm{m}}(T)$-curves for A. implicatum, I. farinosa, and M. alpina (subgroup D) INMs after different treatments. G.Cl stands for guanidinium chloride treatment, and B.A. for boric acid treatment. A reduction of $n_{\mathrm{m}}$ suggests that this method partly or fully destroyed the INMs. The absence of data points despite the listing in the figure legend indicates that $n_{\mathrm{m}}$ lied below the detection limit. For M. alpina, the data are the mean curves of all investigated strains of the phylogenetic subgroup D, which is the most representative (Fröhlich-Nowoisky et al., 2015). The * symbol for A. implicatum and I. farinosa values: these measurements were undertaken with the filtrates of another harvest, which explains the higher values in comparison to the other results.

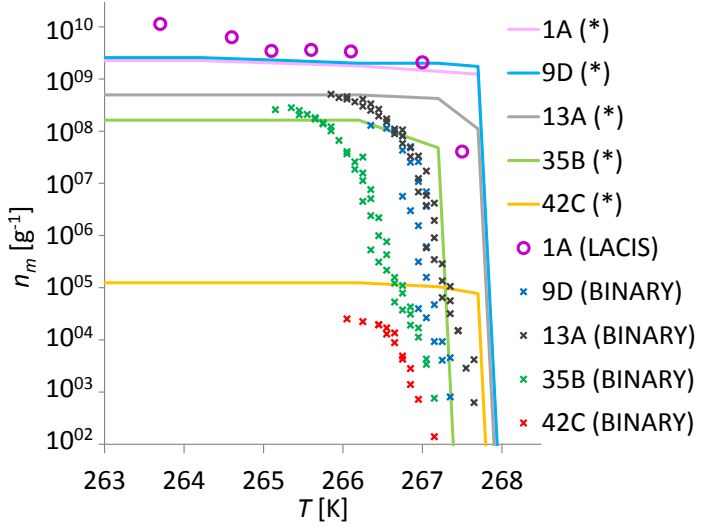

Figure 3. Comparison of ice nucleation curves of $0.1 \mu \mathrm{m}$ filtrates from a few M. alpina strains. The number and letter combination labels the strain. The devices used for generating the respective curves are shown in brackets. * stands for the setup described in FröhlichNowoisky et al. (2015).

a necessity of the setup, which corresponds to a larger critical ice embryo or INM size. We suggest that the birch pollen INMs might be capable of forming aggregates that are larger, active at higher temperatures, but also less frequent. Consequently, they are below the detection limit of INA assay devices with lower material loads per droplet, such as the oil immersion cryo-microscopy.

The examination shows that the 16-amino acid BINM peptide shows INA when a certain concentration in solution is surpassed. This molecule should hardly show INA since its molecular mass is only $1.6 \mathrm{kDa}$ and the number of fitting functional groups is limited to one TXT motif, where T designates threonine and $\mathrm{X}$ any other amino acid. However, these peptides tend to self-assemble into aggregates (Garnham et al., 2011), which consequently follow an equilibrium of formation and decay. These aggregates may have different sizes and shapes, and consequently different INAs.

The $10 \mathrm{mg} \mathrm{mL}^{-1}$ sample showed only homogeneous ice nucleation. The $30 \mathrm{mg} \mathrm{mL}^{-1}$ sample showed an initial freezing temperature at about $250 \mathrm{~K}$, a flat slope of $n_{\mathrm{m}}(T)$ towards lower temperatures, and a $T_{50}$ between 240 and $245 \mathrm{~K}$ in different experiments. The variance is rather high since the aggregate formation seems to be very sensitive to the handling of the sample. This is in contrast to the typical biological INMs, which show a very steep slope at a given temperature and then reach a saturation plateau (e.g., Figs. 2 and 3). Fur- 
ther investigations are in progress to measure the aggregates and get a better understanding of the process.

\subsection{Comparison with theoretical calculations of the critical ice embryo size}

In Fig. 4, we plot the experimentally determined molecular masses of INMs against the observed ice nucleation temperature. For comparison, we show the theoretical parameterization of the critical ice embryo size of Zobrist et al. (2007), which is based on classical nucleation theory. The sources of the plotted data are specified in Table 3. Apart from the fungal and birch pollen INMs investigated in our groups, we added BINM data from Govindarajan and Lindow (1988a), who indicated the good agreement between aggregate size and critical ice embryo size. INA data of polyvinyl alcohol (PVA) were incorporated since it also showed a slight INA in experiments (Ogawa et al., 2009). Its peculiarities are first that the formula is quite simple for a macromolecule, which is a sequence of $\mathrm{CH}_{2} \mathrm{CHOH}$ units, and second, that the chain is rather randomly coiled. Therefore, the near-range molecular order is quite well defined, while the far-range order is merely statistical.

The data of birch pollen and fungal INMs are in acceptable agreement with the theoretical parameterization. We deduce that these free biological INMs which carry a suitable hydration shell mimic a theoretical ice embryo of the same size well enough to show the same INA. However, ice embryos of this size are almost impossible to form spontaneously, which explains the low temperatures that are necessary for homogeneous ice nucleation. In contrast, the biological INMs have a given shape, which explains their high INA.

In the case of PVA, we see that an increase in size does not lead to an appropriate increase in the freezing temperature. This can be easily explained by the different degrees of structure of biological macromolecules and technical homopolymers. Both PVA and BINMs consist of a sequence of monomers covalently linked to each other. Longer chains fold into compact three-dimensional structures. Without any further forces, polymers coil randomly. Therefore, confined geometries do not exceed the size of a few monomers, where the limited flexibility of the monomer-to-monomer bond enforces certain geometries. Hence, an increase in the total INM mass will not increase its INA. In contrast, intact proteins show strongly determined folding, which is held together by intramolecular forces, and sometimes even forced onto them by folding-supporting proteins. Therefore, a native protein's structure is stabilized in a certain geometry as is the molecular surface. The unfolding of a biological macromolecule - a process called denaturation - changes many of its properties. This is also valid for the INA of INMs, and explains their deactivation from heat far below the temperatures where the covalent molecular bonds are broken. It is also responsible for the destruction of most INMs by the chaotropic guanidinium chloride. Summed up, randomly coiled INMs

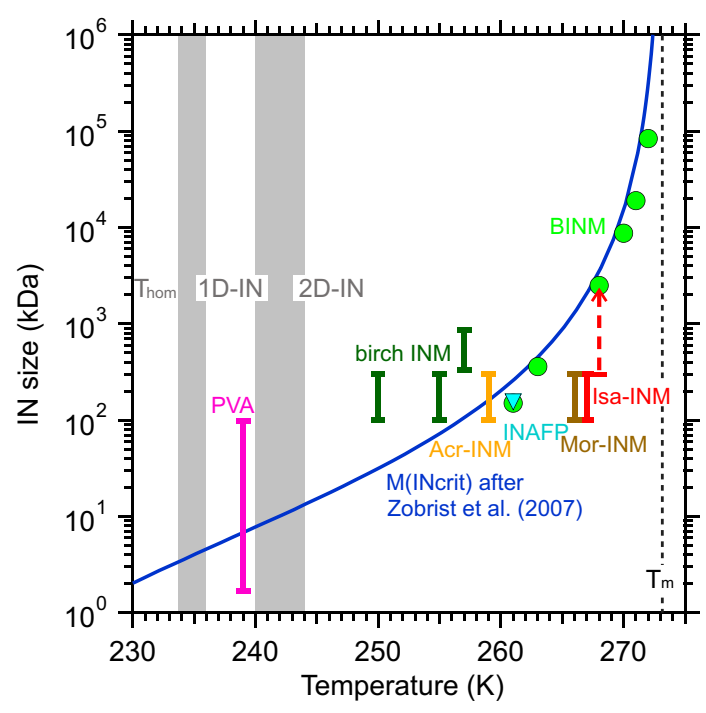

Figure 4. The dependence of the median freezing temperature on size for different types of IN (colored dots). The blue curve is the calculated critical ice cluster size derived from classical nucleation theory (Zobrist et al., 2007). The sources of the presented IN data are listed in Table 3. The graph further shows the region where we assume the domains where 1-D and 2-D templates act as IN. The grey areas mark the transition regions between the domains. The acronyms Acr, Isa, and Mor stand for the respective fungal species.

like PVA allocate only small, one-dimensional templates for ice nucleation (Fig. 1b) and therefore nucleate ice at very low temperatures (Fig. 4). On the other hand, molecules in long-range confined geometries, like the BINM, allocate stable two-dimensional surfaces as ice nucleating templates (Fig. 1c), which are larger and therefore nucleate at higher temperatures (Fig. 4). Also, long-chained alcohols show appreciable INA if they are crystallized in well-defined monolayers, depending on the chain length, the position of the $\mathrm{OH}$ group, and substitutions on the side chains (Popovitz-Biro et al., 1994).

\section{Discussion}

\subsection{Previous findings on biological INMs}

The previously mentioned BINMs that have been found so far are a certain class of bacterial lipoglycoproteins that are fully sequenced and characterized (e.g., Abe et al., 1989). In some cases, biological INMs of one type or species show more than one freezing temperature on an ice nucleation spectrum. This variation in INA can be explained by the presence of different functional groups, foldings, or aggregation states (e.g., Govindarajan and Lindow, 1988a; Augustin et al., 2013; Dreischmeier et al., 2014; this study). The presence of INMs seems to have certain benefits which lead to their expression in several organisms (Sect. S1.5). 
Table 3. Overview over masses $(m)$ and activation temperatures $\left(T_{\text {nuc }}\right)$ of certain IN.

\begin{tabular}{|c|c|c|c|}
\hline Type & Source & $m(\mathrm{kDa})$ & $T_{\text {nuc }}(\mathrm{K})$ \\
\hline BINM ( 560 units) & Burke and Lindow (1990) & $\sim 83700$ & 272 \\
\hline BINM ( 130 units) & Govindarajan and Lindow (1988a) & $\sim 19000$ & 271 \\
\hline BINM ( $\sim 60$ units) & Govindarajan and Lindow (1988a) & $\sim 8700$ & 270 \\
\hline BINM ( $\sim 20$ units) & Govindarajan and Lindow (1988a) & $\sim 2500$ & 268 \\
\hline Crit. ice embryo & Zachariassen and Kristiansen (2000) & 810 & 268 \\
\hline Isa-INM (> 1 units) & this study & $>300$ & 268 \\
\hline Isa-INM (1 unit) & this study & $100-300$ & 267 \\
\hline Mor-INM & Fröhlich-Nowoisky et al. (2015) & $100-300$ & 266 \\
\hline BINM (3 units) & Gurian-Sherman and Lindow (1995) & $\sim 360$ & 263 \\
\hline BINM (1 unit) & Govindarajan and Lindow (1988a) & $\sim 150$ & 261 \\
\hline INAFP & Xu et al. (1998) & 164 & 261 \\
\hline Acr-INM & this study & $100-300$ & 259 \\
\hline birch INM & this study & $335-860$ & 257 \\
\hline birch INM & Pummer et al. (2012) & $100-300$ & 255 \\
\hline birch INM* & Augustin et al. (2013) & $100-300$ & 250 \\
\hline PVA & Ogawa et al. (2009) & 1.7-98 & 239 \\
\hline Crit. ice embryo & Zachariassen and Kristiansen (2000) & 1.26 & 233 \\
\hline
\end{tabular}

The bacterial gene is highly conserved and codes for a $120 \mathrm{kDa} \beta$-helical membrane protein with many repeated octapeptides (Green and Warren, 1985; Abe et al., 1989; Kajava and Lindow, 1993; Schmid et al., 1997; Graether and Jia, 2001; Garnham et al., 2011). The INA induced by this protein also involves glycosides and lipids that stabilize it in the outer membrane of the bacterial cell and assure its conformation for optimum functioning (Kozloff et al., 1984; Govindarajan and Lindow, 1988a; Turner et al., 1991; Kawahara, 2002). With the side chains, the total mass of a single BINM is about $150-180 \mathrm{kDa}$ (Table 1). It is assumed that the initiation point for ice formation is the amino acid sequence TXT in the repeated octapeptide, where T designates threonine and $\mathrm{X}$ any other amino acid. The $\mathrm{OH}$ groups of the two threonine moieties match the position of oxygen atoms in the ice lattice. Since a BINM contains several of these sequences at positions and distances that correspond to the ice lattice structure, it can stabilize an ice embryo and so decrease the activation barrier for ice nucleation (Graether and Jia, 2001). As sequence modification studies on a structurally related antifreeze protein have shown, the loss of the TXT has a devastating effect on the interaction with water molecules, while other modifications have a much weaker impact (Graether et al., 2000).

The expression of BINMs is an exclusive property of certain bacterial species. It has been reported for a wide range of strains in the $P$. syringae species complex (Lindow et al., 1982; Berge et al., 2014), P. fluorescens and borealis (Fall and Schnell, 1985; Obata et al., 1987; Foreman et al., 2013), Erwinia uredovora (Obata et al., 1990a), Pantoea agglomerans (formerly called E. herbicola; Phelps et al., 1986), Pantoea ananatis (Coutinho and Venter, 2009), Xanthomonas campestris (Kim et al., 1987), a Pseudoxanthomonas sp. (Joly et al., 2013), and more. The efficacy of their INA depends on both the strain and the cultural growth conditions, e.g., available nutrients and growth temperature (Rogers et al., 1987; Nemecek-Marshall et al., 1993; Fall and Fall, 1998). In most cases, these BINMs are aggregated and anchored in the outer cell membrane, where the strength of the INA depends on the aggregation state and the chemistry of the membrane (Govindarajan and Lindow, 1988a, b; Kozloff et al., 1991). However, free BINMs still show appreciable INA, although less than in the native state (Schmid et al., 1997). Since these complexes of aggregated BINMs exhibit a large surface that matches the ice crystal lattice almost perfectly, the bacteria expressing them are the most active IN known at present.

These anchored aggregates of BINMs on the otherwise ice nucleation inactive cell surface are a demonstrative example of active sites on a larger IN, which is the microsized bacterial cell. In some cases, bacteria release their active sites carried on much smaller membrane vesicles. These are spherical pieces of the outer cellular membrane that are excised from the cell, a natural and common phenomenon in bacteria in general (Deatherage and Cookson, 2012). The expression of such vesicles with BINMs has been reported for Pantoea agglomerans/E. herbicola (Phelps et al., 1986), E. uredovora (Kawahara et al., 1993), and P. fluorescens (Obata et al., 1993). P. syringae and viridiflava express such BINM-carrying vesicles only under certain growth conditions (Obata et al., 1990b; Pooley and Brown, 1990). For $P$. putida, the INA found in culture supernatants was associated 
with a $164 \mathrm{kDa}$ lipoglycoprotein and had activity both as an IN and as an antifreeze protein. In this case, removal of the approximately $92 \mathrm{kDa}$ of carbohydrates eliminated the INA but not the antifreeze properties (Xu et al., 1998).

INMs have also been found in the Fungi kingdom (Jayaweera and Flanagan, 1982; Kieft, 1988; Kieft and Ahmadjian, 1989; Kieft and Ruscetti, 1990; Pouleur et al., 1992; Hasegawa et al., 1994; Tsumuki and Konno, 1994; Tsumuki et al., 1995; Richard et al., 1996; Humphreys et al., 2001; Morris et al., 2013; Haga et al., 2014; Fröhlich-Nowoisky et al., 2015). Similarly to the bacteria, only a limited fraction of investigated strains showed INA, while the majority was inactive (Pouleur et al., 1992; Tsumuki et al., 1995; Iannone et al., 2011; Pummer et al., 2013a; Huffman et al., 2013; Fröhlich-Nowoisky et al., 2015). Fungal INMs can be divided into two subgroups, both of which differ from the BINMs. The INMs of rust fungi show properties of polysaccharide compounds (Morris et al., 2013). The previously characterized INMs from Rhizoplaca chrysoleuca (Kieft and Ruscetti, 1990), F. avenaceum (Pouleur et al., 1992; Hasegawa et al., 1994; Tsumuki and Konno, 1994), and M. alpina (Fröhlich-Nowoisky et al., 2015) are evidently proteins, but show hardly any other similarities with the BINMs. They are more tolerant to stresses, have a different amino acid sequence, seem to have less to no lipid and carbohydrate functionalizing, and are easily released from the cells. Only recently was a $49 \mathrm{kDa}$ protein from $F$. acuminatum suggested as being the INM (Lagzian et al., 2014).

Proteins and lipoproteins with INA were also found in extracellular fluids of insects like Tipula trivittata larvae (Duman et al., 1985, 1991; Neven et al., 1989; Warren and Wolber, 1991), Vespula maculata queens (Duman et al., 1984), and Dendroides canadensis larvae (Olsen and Duman, 1997). The only non-proteinaceous insect INs found up to date are phosphate spherules and fat cells in the larvae of Eurosta solidaginis (Mugnano et al., 1996). INs have also been detected in other animal taxa, e.g., amphibians (Wolanczyk et al., 1990) and mollusks (Aunaas, 1982; Hayes and Loomis, 1985; Madison et al., 1991; Lundheim, 1997), as well as in spider silk (Murase et al., 2001).

The fluid reservoirs of some succulent plants, namely $L o$ belia telekii and Opuntia species, contain polysaccharide INMs (Krog et al., 1979; Goldstein and Nobel, 1991, 1994). Other reported non-proteinaceous plant INs are from the wood of Prunus species (Gross et al., 1988), and the lignin in a waste water sample (Gao et al., 1999). Among plant INs, only those of Secale cereale were identified as proteins (Brush et al., 1994). The pollen of some plant species showed appreciable INA in different lab studies, among which that of the silver birch (Betula pendula or alba) was the most active (Diehl et al., 2001, 2002; von Blohn et al., 2005; Pummer et al., 2012; Augustin et al., 2013). Birch pollen contain easily extractable, very robust INMs, which are non-proteinaceous and most likely some type of polysaccharide (Pummer et al., 2012). The extracts were characterized using vibrational spectroscopy, which indicated that they contained sugar-like compounds, proteins, and other biological molecules, but no sporopollenin, which is the fabric of the outer pollen wall (Pummer et al., 2013b).

Other organic aerosols which have been the focus of ice nucleation research are humic-like substances (HULIS) and secondary organic aerosols (SOAs). They show certain similarities to the presented INMs since they consist of a large variety of organic macromolecules that have undergone complex biochemical processing. Analogously, several exponents showed little to no INA in experiments, or even oppressed INA in mixed particles by blocking active sites (e.g., Möhler et al., 2008; Prenni et al., 2009), while others showed appreciable INA. Certain HULIS (Wang and Knopf, 2011) and some SOAs (Wang et al., 2012; Schill et al., 2014) induced ice nucleation in the deposition and the immersion mode. The $\mathrm{O} / \mathrm{C}$ ratio of the latter did not affect the INA, although it influenced several other properties, such as the kinetics of the water uptake, in agreement with recent model simulations (Berkemeier et al., 2014). Among glassy aerosols composed of saccharidic components, some chemical species showed significant INA that might even compete with mineral dust INA in mid-latitude clouds (Wilson et al., 2012). Even a simple compound like citric acid shows INA when it is in the state of a glassy aerosol (Murray et al., 2010). Alternatively, other organic compounds such as oxalic acid can act as an immersion IN in the crystalline state (Zobrist et al., 2006; Wagner et al., 2011) Also, cellulose, which is the most common biopolymer on Earth due to its ubiquity in plant cell walls, shows INA in the form of microcrystalline or fibrous particles (Hiranuma et al., 2015). The inorganic salt ammonium sulfate possesses INA in the crystalline state in both the immersion and deposition mode, despite it being a highly soluble compound (Zuberi et al., 2001; Abbatt et al., 2006).

\subsection{Solubility of INMs}

In atmospheric science, INs are traditionally regarded as insoluble particles on the surface of which ice nucleation takes place. According to Raoult's law, soluble substances are expected to decrease the freezing point with increasing molar concentration. Furthermore, any ice nucleating template requires a certain size to be able to support a critical ice embryo that is large enough to grow into a macroscopic crystal. Consequently, particles that dissociate into molecules or ions with low molar mass in solution (e.g., $\mathrm{NaCl}$, and mono- and disaccharides) cannot act as IN. However, data from Pummer et al. (2012) showed that the ice nucleation active components of pollen have a mass between 100 and $300 \mathrm{kDa}$. This means that the INs have the size of single macromolecules. If these molecules are fully dissolved in water, one can regard them as being in solution and not in suspension. Many proteins are soluble in water (e.g., Osborne, 1910; Macedo, 2005; Sect. S1.1), but single protein 
molecules are far larger than e.g., salt ions or low molecular weight saccharides. Therefore, a deviation from the simplistic approach of Raoult's law is expected. In this case, a soluble compound can also act as an IN if the active molecular surface is large enough to stabilize ice embryos of critical size. The freezing point depression is expected to be rather weak for a dissolved $>100 \mathrm{kDa}$ molecule because even a high mass concentration correlates with only a low molar concentration. The resulting small reduction of the solution's water activity is likely to affect the heterogeneous ice nucleation temperature only slightly (Sect. S1.4, Koop and Zobrist, 2009; Attard et al., 2012). Accordingly, certain macromolecules can act as IN in spite of being water-soluble because the water-structuring effect overcompensates for the colligative freezing point depression. Most molecules carry a well-defined hydration shell. In the case of INMs, the geometry of water molecules in the hydration shell is supposedly similar to the geometry in an ice embryo, which triggers the freezing process (Fig. 1). We therefore emphasize that a more molecular view of IN allows for a better understanding of the process of heterogeneous ice nucleation. For example, the contact angle, which is useful in atmospheric models, is a macroscopic interpretation of the affinity between two phases: the ice embryo and the IN. Water molecules show a high affinity towards hydroxy (-OH) and amino ($\mathrm{NH}_{2}$ ) groups since they form hydrogen bonds with them. The contact angle quantifies the outcome of the molecular interaction and allows for the comparison of different INs, but it does not allow one to trace back the complex molecular structures that are responsible. If we understand which structures are the characteristics of INMs, it will make predictions of INA possible for any macromolecule with a known sequence. As an example, the previously mentioned TXT sequences (Sect. 4.1) are one such element that foster INA, but there must be others as well since non-proteinaceous INs exist. Classification and precise characterization of the currently known INs might reveal other INA elements.

As shown in Fig. 4, molecular size and INA exhibit a positive correlation. Deviations from the model line can be explained by different properties of different types of INMs. If molecules are larger than expected, like for birch pollen INMs, the active site might not cover the whole molecule, but just a small part of it. The INMs of I. farinosa and $M$. alpina seem to be too small. This can be either explained by spontaneous aggregation of several molecules after the filtration step, or by the ability to form a larger hydration shell, which has to be taken into account. Also, when data were derived from measurements in which droplets were examined which contain higher numbers of INM per droplet, the freezing temperature is shifted to higher temperatures, as can be seen, e.g., when comparing data of birch pollen from Pummer et al. (2012) and Augustin et al. (2013). Very speculatively, one could try to go the other way and use experimentally determined freezing temperatures of IN, e.g., mineral dust and soot, to roughly estimate the size of their active sites.
In combination with chemical and structural analyzing of the IN, one could try to identify which elements of these IN can be considered to be responsible for the INA. Considerations about the INA and active sites of mineral dust are given in Sect. S1.6.

\subsection{Potential atmospheric effects}

Apart from its cryobiological and evolutionary aspect, heterogeneous ice nucleation is of high importance for atmospheric research since it causes cloud glaciation and therefore impacts the global radiation budget (albedo) and initiates precipitation.

A common argument against the atmospheric INA potential of bioaerosols is that whole cells which are at least some micrometers in size are far too large to reach altitudes higher than a few kilometers. However, the detection of cultivable microorganisms, even in the mesosphere (Imshenetsky et al., 1978), shows that there have to be mechanisms that elevate intact cells to the higher atmosphere despite their size. As an example, the atmospheric turbulence caused by volcanic activity support a high- and far-range distribution of all kinds of aerosols (van Eaton et al., 2013). Furthermore, certain pollen (e.g., pine) and fungal spores (e.g., urediospores) are very buoyant, as they possess wing-like projections and other aerodynamic surface properties. Urediospores have been collected from the air at over $3 \mathrm{~km}$ above the ground level along with other microorganisms (Stakman and Christensen, 1946). Cultivable microorganisms are also present in the stratosphere (Griffin, 2004) and in cloud water samples (e.g., Vaitilingom et al., 2012; Joly et al., 2013). Even more intriguingly, some of these organisms are even able to proliferate in supercooled cloud droplets (e.g., Sattler et al., 2001).

Biological cells are not rigid spheres, but rather a composition of many different membranes, organelles, and fluids, which further consist of many different molecules, ranging from water to small organic molecules to biopolymers. Therefore, the release of molecular matter, as well as cell fragmentation, is common. Several studies have detected molecular tracers from pollen grains and fungi in atmospheric fine particulate matter even in the absence of whole cells (e.g., Solomon et al., 1983; Yttri et al., 2007). In most cases, biological INMs are easily released from the producing cell (Table 1). Since a single primary biological particle can carry up to hundreds and thousands of INMs, and since the INMs are also much lighter, we expect their atmospheric concentration to be significantly higher as well. A possible mechanism of INM release is cell rupture caused by a rapid change in moisture. Scanning electron microscopy studies on wet pollen back up this idea by visualizing the release of organelles and organic matter (Grote et al., 2001, 2003; Pummer et al., 2013b). This explains why rainfall, which is expected to wash out aerosols, can indeed increase the concentration of allergens (Schäppi et al., 1997) or INs (Huffman 
et al., 2013) in the air. Recently, the presence of nanosized biological particles with INA were detected in precipitation (Santl-Temkiv et al., 2015) and soil (O'Sullivan et al., 2015).

Quantifying the atmospheric impact of fungi is even more difficult as presumably 1 to 5 million fungal species exist (Hawksworth, 2001). Due to mutation and adaptation, every species consists of numerous strains, which differ in their INA (Tsumuki et al., 1995). Even if all studies are combined, it is only a minor fraction of all fungal species that have been tested for their INA. Furthermore, the expression of INMs is triggered by yet unknown conditions, which could be the availability of nutrients, the local climate or competition with other microorganisms. As a consequence, INA-positive strains can lose their activity when they are cultivated under laboratory conditions (Tsumuki et al., 1995; Pummer et al., 2013a). Therefore, more atmospheric IN counting and sampling will be necessary to understand the contribution of biological INA better.

Several former studies have focused on quantifying biological INs either by analyzing precipitation samples (Christner et al., 2008a, b), or by atmospheric modeling based on emission and deposition data (Hoose et al., 2010). In both cases, however, only whole cells were examined. Christner et al. $(2008 \mathrm{a}, \mathrm{b})$ filtered the particles of interest out of the samples, and so lost the molecular fraction, which contains the INMs we described. Hoose et al. (2010) did not include fragmentation or phase separation processes that can release molecular compounds from the carrier particles in the atmosphere. This might have led to an underestimation of the atmospheric relevance of biological INs.

\section{Conclusions}

Even free water-soluble macromolecules are able to nucleate ice since they are in the same size range as the critical ice embryos. INMs can be diverse in chemical structure and origin, which may range from biopolymers in primary biological aerosols (proteins, saccharides, lipids, hybrid compounds), to secondary organic aerosol components (HULIS, etc.), to synthetic polymers (PVA).

The allocation of functional groups, as well as the confinement that keeps them in place, is essential for the efficacy of the INMs. An increase of the template size that can be realized by aggregation of single molecules also leads to an enhancement of the INA. In this study we have shown that the water-soluble INMs from the fungal species $A$. implicatum and I. farinosa are proteins, and we have obtained additional evidence that the birch pollen INMs are polysaccharides without relevant protein content.

Water-soluble INMs are released by a wide range of biological species. They may be associated not only with primary biological aerosols but also with other atmospheric aerosol particles such as soil dust or sea spray. The potential effects of such INMs should be considered and pose an ad- ditional challenge to the quantification and assessment of the importance of biological ice nucleation in the atmosphere.

\section{The Supplement related to this article is available online at doi:10.5194/acp-15-4077-2015-supplement.}

Acknowledgements. We thank the Max Planck Society and the INUIT Research Unit (projects PO1013/5-1, KO2944/2-1, and WE4722/1-1; all for INUIT 1525) for project funding. We acknowledge M. Linden and D. Sebazungu for technical support, as well as Z. Dráb from Pharmallerga ${ }^{\circledR}$ for the donation of the birch pollen.

D. Niedermeier acknowledges financial support from the Alexander von Humboldt Foundation. H. Grothe and T. Loerting are grateful for support from the Austrian Science Fund (FWF; projects P23027 and P26040). We thank the European Science Foundation for funding the workshops on ice nucleation within the research networking programme MicroDICE in the years 2013, 2014, and 2015.

The article processing charges for this open-access publication were covered by the Max Planck Society.

Edited by: A. Bertram

\section{References}

Abbatt, J. P. D., Benz, S., Cziczo, D. J., Kanji, Z., Lohmann, U., and Möhler, O.: Solid ammonium sulfate aerosols as ice nuclei: a pathway for cirrus cloud formation, Science, 22, 313, 17701773, doi:10.1126/science.1129726, 2006.

Abe, K., Watabe, S., Emori, Y., Watanabe, M., and Arai, S.: An ice nucleation gene of Erwinia ananas, FEBS Lett., 258, 297-300, doi:10.1016/0014-5793(89)81678-3, 1989.

Attard, E., Yang, H., Delort, A.-M., Amato, P., Pöschl, U., Glaux, C., Koop, T., and Morris, C. E.: Effects of atmospheric conditions on ice nucleation activity of Pseudomonas, Atmos. Chem. Phys., 12, 10667-10677, doi:10.5194/acp-12-10667-2012, 2012.

Augustin, S., Wex, H., Niedermeier, D., Pummer, B., Grothe, H., Hartmann, S., Tomsche, L., Clauss, T., Voigtländer, J., Ignatius, K., and Stratmann, F.: Immersion freezing of birch pollen washing water, Atmos. Chem. Phys., 13, 10989-11003, doi:10.5194/acp-13-10989-2013, 2013.

Aunaas, T.: Nucleating agents in the haemolymph of an intertidal mollusc tolerant to freezing, Cell. Mol. Life Sci., 38, 1456-1457, 1982.

Berge, O., Monteil, C. L., Bartoli, C., Chandeysson, C., Guilbaud, C., Sands, D. C., and Morris, C. E.: A user's guide to a data base of the diversity of Pseudomonas syringae and its application to classifying strains in this phylogenetic complex, PLOS ONE, 9, e105547, doi:10.1371/journal.pone.0105547, 2014.

Berkemeier, T., Shiraiwa, M., Pöschl, U., and Koop, T.: Competition between water uptake and ice nucleation by glassy organic aerosol particles, Atmos. Chem. Phys., 14, 12513-12531, doi:10.5194/acp-14-12513-2014, 2014. 
Brush, R. A., Griffith, M., and Mlynarz, A.: Characterization and quantification of intrinsic ice nucleators in winter rye (Secale cereale) leaves, Plant Physiol., 104, 725-735, 1994.

Budke, C. and Koop, T.: BINARY: an optical freezing array for assessing temperature and time dependence of heterogeneous ice nucleation, Atmos. Meas. Tech., 8, 689-703, doi:10.5194/amt-8689-2015, 2015.

Burke, M. J. and Lindow, S. E.: Surface properties and size of the ice nucleation site in ice nucleation active bacteria: theoretical considerations, Cryobiology, 27, 88-84, 1990.

Christner, B. C., Cai, R., Morris, C. E., McCarter, K. S., Foreman, C. M., Skidmore, M. L., Montross, S. N., and Sands, D. C.: Geographic, seasonal, and precipitation chemistry influence on the abundance and activity of biological ice nucleators in rain and snow, P. Natl. Acad. Sci., 105, 18854-18859, 2008 a.

Christner, B. C., Morris, C. E., Foreman, C. M., Cai, R. and Sands, D. C.: Ubiquity of biological ice nucleators in snowfall, Science, 319, 1214, doi:10.1126/science.1149757, 2008b.

Coutinho, T. A. and Venter, S. N.: Pantoea ananatis: an unconventional plant pathogen, Mol. Plant. Pathol., 10, 325-335, 2009.

Deatherage, B. L. and Cookson, B. T.: Membrane vesicle release in bacteria, eukaryotes, and archaea: a conserved yet underappreciated aspect of microbial life, Infect. Immun., 80, 1948-1957, 2012

Diehl, K., Quick, C., Matthias-Maser, S., Mitra, S. K., and Jaenicke, R.: The ice nucleation ability of pollen Part I: Laboratory studies in deposition and condensation freezing modes, Atmos. Res., 58, 75-87, 2001.

Diehl, K., Matthias-Maser, S., Jaenicke, R., and Mitra, S. K.: The ice nucleation ability of pollen Part II: Laboratory studies in immersion and contact freezing modes, Atmos. Res., 61, 125-133, 2002.

Dreischmeier, K., Budke, C., and Koop, T.: Investigation of heterogeneous ice nucleation in pollen suspensions and washing water, EGU2014-8653, Geophys. Res. Abstracts, 16, 2014.

Duman, J. G., Morris, J. P., and Castellino, F. J.: Purification and composition of an ice nucleating protein from queens of the hornet, Vespula maculata, J. Comp. Physiol. B, 154, 79-83, 1984.

Duman, J. G., Neven, L. G., Beals, J. M., Olson, K. R., and Castellino, F. J.: Freeze-tolerance adaptations, including haemolymph protein and lipoprotein nucleators, in the larvae of the cranefly Tipula trivittata, J. Insect Physiol., 31, 1-8, 1985.

Duman, J. G., Wu, D. W., Wolber, P. K., Mueller, G. M., and Neven, L. G.: Further characterization of the lipoprotein ice nucleator from freeze tolerant larvae of the cranefly Tipula trivittata, Comp. Biochem. Physiol., 99B, 599-607, 1991.

Edwards, G. R., Evans, L. F., and La Mer, V. K.: Ice nucleation by monodisperse silver iodide particles, J. Coll. Sci. Imp. U. Tok., 17, 749-758, doi:10.1016/0095-8522(62)90049-1, 1962.

Erickson, H. P.: Size and shape of protein molecules at the nanometer level determined by sedimentation, gel filtration, and electron microscopy, Biol. Proced. Online, 11, 32-51, doi:10.1007/s12575-009-9008-x, 2009.

Fall, A. L. and Fall, R.: High-level expression of ice nuclei in Erwinia herbicola is induced by phosphate starvation and low temperature, Curr. Microbiol., 36, 370-376, 1998.

Fall, R. and Schnell, R. C.: Association of an ice-nucleating pseudomonad with cultures of the marine dinoflagellate, Heterocapsa niei, J. Marine Res., 43, 257-265, 1985.
Foreman, C. M., Cory, R. M., Morris, C. E., SanClements, M. D., Lisle, J., Miller, P. L., Chin, Y. C., and McKnight, D. M.: Microbial growth under humic-free conditions in a supraglacial stream system on the Cotton Glacier, Antarctica, Environ. Res. Lett., 8, 035022, doi:10.1088/1748-9326/8/3/035022, 2013.

Fröhlich-Nowoisky, J., Hill, T. C. J., Pummer, B. G., Yordanova, P., Franc, G. D., and Pöschl, U.: Ice nucleation activity in the widespread soil fungus Mortierella alpina, Biogeosciences, 12, 1057-1071, doi:10.5194/bg-12-1057-2015, 2015.

Fukuta, N.: Experimental studies of organic ice nuclei, J. Atmos. Sci., 23, 191-196, 1966.

Gao, W., Smith, D. W., and Sego, D. C.: Ice nucleation in industrial wastewater, Cold Reg. Sci. Technol., 29, 121-133, 1999.

Garnham, C. P., Campbell, R. L., Walker, V. K., and Davies, P. L.: Noveldimeric $\beta$-helical model of an ice nucleation protein with bridged active sites, BMC Struct. Biol., 11, 36, doi:10.1186/1472-6807-11-36, 2011

Goldstein, G. and Nobel, P. S.: Changes in osmotic pressure and mucilage during low-temperature acclimation of Opuntia ficusindica, Plant Physiol., 97, 954-961, 1991.

Goldstein, G. and Nobel, P. S.: Water relations and low-temperature acclimation for cactus species varying in freezing tolerance, Plant Physiol., 104, 675-681, 1994.

Govindarajan, A. G. and Lindow, S. E.: Size of bacterial icenucleation sites measured in situ by radiation inactivation analysis, P. Natl. Acad. Sci. USA, 85, 1334-1338, 1988a.

Govindarajan, A. G. and Lindow, S. E.: Phospholipid requirement for expression of ice nuclei in Pseudomonas syringae and in vitro, J. Biol. Chem., 263, 9333-9338, 1988b.

Graether, S. P. and Jia, Z.: Modeling Pseudomonas syringae icenucleation proteins as a $\beta$-helical protein, Biophys. J., 80, 1169 1173, 2001.

Graether, S. P., Kulper, M. J., Gagné, S. M., Walker, V. K., Jia, Z., Sykes, B. D., and Davies, P. L.: $\beta$-helix structure and ice-binding properties of a hyperactive antifreeze protein from an insect, Nature, 406, 325-328, 2000.

Green, R. L. and Warren, G. J.: Physical and functional repetition in a bacterial ice nucleation gene, Nature, 317, 645-648, 1985.

Griffin, D. W.: Terrestrial microorganisms at an altitude of $20.000 \mathrm{~m}$ in Earth's atmosphere, Aerobiologia, 20, 135-140, 2004.

Gross, D. C., Proebsting, E. L., and Maccrindle-Zimmermann, H.: Development, distribution, and characteristics of intrinsic, nonbacterial ice nuclei in Prunus wood, Plant Physiol., 88, 915-922, 1988.

Grote, M., Vrtala, S., Niederberger, V., Wiermann, R., Valenta, R., and Reichelt, R.: Release of allergen-bearing cytoplasm from hydrated pollen: A mechanism common to a variety of grass (Poaceae) species revealed by electron microscopy, J. Allerg. Clin. Immunol., 108, 109-115, doi:10.1067/mai.2001.116431, 2001.

Grote, M., Valenta, R., and Reichelt, R.: Immunogold scanning electron microscopy of abortive pollen germination: how birch, hazel, and alder release allergenic particles into the atmosphere, Microsc. Microanal., 9, Suppl. S03, 402-403, 2003.

Gurian-Sherman, D. and Lindow, S. E.: Differential effects of growth temperature on ice nuclei active at different temperatures that are produced by cells of Pseudomonas syringae, Cryobiol. 32, 129-138, 1995. 
Haga, D. I., Burrows, S. M., Iannone, R., Wheeler, M. J., Mason, R. H., Chen, J., Polishchuk, E. A., Pöschl, U., and Bertram, A. K.: Ice nucleation by fungal spores from the classes Agaricomycetes, Ustilaginomycetes, and Eurotiomycetes, and the effect on the atmospheric transport of these spores, Atmos. Chem. Phys., 14, 8611-8630, doi:10.5194/acp-14-8611-2014, 2014.

Hartmann, S., Niedermeier, D., Voigtländer, J., Clauss, T., Shaw, R. A., Wex, H., Kiselev, A., and Stratmann, F.: Homogeneous and heterogeneous ice nucleation at LACIS: operating principle and theoretical studies, Atmos. Chem. Phys., 11, 1753-1767, doi:10.5194/acp-11-1753-2011, 2011.

Hasegawa, Y., Ishihara, Y., and Tokuyama, T.: Characteristics of ice-nucleation activity in Fusarium avenaceum IFO 7158, Biosci. Biotech. Biochem., 58, 2273-2274, 1994.

Hawksworth, D. L.: The magnitude of fungal diversity: the 1-5 million species estimate revisited, Mycol. Res., 105, 1422-1432, doi:10-1017/S0953756201004725, 2001.

Hayes, D. R. and Loomis, S. H.: Evidence for a proteinaceous ice nucleator in the hemolymph of the pulmonate gastropod, Melampus bidentatus, Cryo-Lett., 6, 418-421, 1985.

Hiranuma, N., Möhler, O., Yamashita, K., Tajiri, T., Saito, A., Kiselev, A., Hoffmann, N., Hoose, C., Jantsch, E., Koop, T., and Muramaki, M.: Ice nucleation by cellulose and its potential contribution to ice formation in clouds, Nat. Geosci., 8, 273-277, doi:10.1038/ngeo2374, 2015 .

Hoose, C., Kristjánsson, J. E., and Burrows, S. M.: How important is biological ice nucleation in clouds on a global scale? Environ. Res. Lett., 5, 024009, doi:10.1088/1748-9326/5/2/024009, 2010.

Huffman, J. A., Prenni, A. J., DeMott, P. J., Pöhlker, C., Mason, R. H., Robinson, N. H., Fröhlich-Nowoisky, J., Tobo, Y., Després, V. R., Garcia, E., Gochis, D. J., Harris, E., Müller-Germann, I., Ruzene, C., Schmer, B., Sinha, B., Day, D. A., Andreae, M. O., Jimenez, J. L., Gallagher, M., Kreidenweis, S. M., Bertram, A. K., and Pöschl, U.: High concentrations of biological aerosol particles and ice nuclei during and after rain, Atmos. Chem. Phys., 13, 6151-6164, doi:10.5194/acp-13-6151-2013, 2013.

Humphreys, T. L., Castrillo, L. A., and Lee, M. R.: Sensitivity of partially purified ice nucleation activity of Fusarium acuminatum SRSF 616, Curr. Microbiol., 42, 330-338, doi:10.1007/s002840010225, 2001.

Iannone, R., Chernoff, D. I., Pringle, A., Martin, S. T., and Bertram, A. K.: The ice nucleation ability of one of the most abundant types of fungal spores found in the atmosphere, Atmos. Chem. Phys., 11, 1191-1201, doi:10.5194/acp-11-1191-2011, 2011.

Imshenetsky, A. A., Lysenko, S. V., and Kazakov, G. A.: Upper boundary ofthe biosphere, Appl. Environ. Microbiol., 35, 1-5, 1978.

Jayaweera, K. and Flanagan, P.: Investigations on biogenic ice nuclei in the Arctic atmosphere, Geophys. Res. Lett., 9, 94-97, 1982.

Joly, M., Attard, E., Sancelme, M., Deguillaume, L., Guilbaud, C., Morris, C. E., Amato, P., and Delort, A. M.: Ice nucleation activity of bacteria isolated from cloud water, Atmos. Environ., 70, 392-400, 2013.

Kajava, A. V. and Lindow, S. E.: A model of the three-dimensional structure of ice nucleation proteins, J. Mol. Biol., 232, 709-717, doi:10.1006/jmbi.1993.1424, 1993.
Katz, U.: Wolkenkammeruntersuchungen der Eiskeimbildungsaktivität einiger ausgewählter Stoffe, Zeitschr. Angew. Math. Phys., 13, 333-358,(in German), 1962.

Kawahara, H.: The structures and functions of ice crystalcontrolling proteins from bacteria, J. Biosci. Bioengineer., 94, 492-496, 2002.

Kawahara, H., Mano, Y., and Obata, H.: Purification and characterization of extracellular ice-nucleating matter from Erwinia uredovora KUIN-3, Biosci. Biotech. Biochem., 57, 1429-1432, 1993.

Kieft, T. L.: Ice nucleation activity in lichens, Appl. Environ. Microbiol., 54, 1678-1681, 1988.

Kieft, T. L. and Ahmadjian, V.: Biological ice nucleation activity in lichen mycobionts and photobionts, Lichenol., 21, 355-362, 1989.

Kieft, T. L. and Ruscetti, T.: Characterization of biological ice nuclei from a lichen, J. Bacteriol., 172, 3519-3523, 1990.

Kim, H. K., Orser, C., Lindow, S. E., and Sands, D. C.: Xanthomonas campestris pv. translucens strains active in ice nucleation, Plant Disease, 71, 994-997, 1987.

Koop, T.: Homogeneous Ice Nucleation in Water and Aqueous Solutions, Zeitschrift für Phys. Chemie, 218, 1231-1258, doi:10.1524/zpch.218.11.1231.50812, 2004.

Koop, T. and Zobrist, B.: Parameterizations for ice nucleation in biological and atmospheric systems, Phys. Chem. Chem. Phys., 11, 10741-11064, doi:10.1039/b914289d, 2009.

Kozloff, L. M., Lute, M., and Westaway, D.: Phosphatidylinositol as a component of the ice nucleating site of Pseudomonas syringae and Erwinia herbicola, Science, 226, 845846, doi:10.1126/science.226.4676.845, 1984.

Kozloff, L. M., Turner, M. A., Arellano, F., and Lute, M.: Formation of bacterial membrane ice-nucleating lipoglycoprotein complexes, J. Bacteriol., 173, 2053-2060, 1991.

Krog, J. O., Zachariassen, K. E., Larsen, B., and Smidsrod, O.: Thermal buffering in Afro-alpine plants due to nucleating agent-induced water freezing, Nature, 282, 300-301, doi:10.1038/282300a0, 1979.

Lagzian, M., Latifi, A. M., Bassami, M. R., Mirzaei, M.: An ice nucleation protein from Fusarium acuminatum: cloning, expression, biochemical characterization and computational modeling, Biotechnol. Lett., 36, 2043-2051, doi:10.1007/s10529-0141568-4, 2014.

Lindow, S. E., Amy, D. C., and Upper, C. D.: Bacterial ice nucleation - a factor in frost injury to plants, Plant Physiol., 70, 10841089, 1982.

Liou, Y. C., Tocilj, A., Davies, P. L., and Jia, Z.: Mimicry of ice structure by surface hydroxyls and water of a $\beta$-helix antifreeze protein, Nature, 406, 322-325, 2000.

Lundheim, R.: Ice nucleation in the blue mussel (Mytilus edulis), Marine Biol., 128, 267-271, 1997.

Macedo, E. A.: Solubility of amino acids, sugars, and proteins, Pure Appl. Chem., 77, 559-568, doi:10.1351/pac200577030559, 2005.

Madison, D. L., Scrofano, M. M., Ireland, D. C., and Loomis, S. H.: Purification and partial characterization of an ice nucleator protein from the intertidal gastropod, Melampus bidentatus, Cryobiol., 28, 483-490, 1991.

Marcolli, C., Gedamke, S., Peter, T., and Zobrist, B.: Efficiency of immersion mode ice nucleation on surrogates of mineral dust, 
Atmos. Chem. Phys., 7, 5081-5091, doi:10.5194/acp-7-50812007, 2007.

Möhler, O., Benz, S., Saathoff, H., Schnaiter, M., Wagner, R., Schneider, J., Walter, S., Ebert, V., and Wagner, S.: The effect of organic coating on the heterogeneous ice nucleation efficiency of mineral dust aerosols, Environ. Res. Lett., 3, 025007, doi:10.1088/1748-9326/3/2/025007, 2008.

Morris, C. E., Sands, D. C., Glaux, C., Samsatly, J., Asaad, S., Moukahel, A. R., Gonçalves, F. L. T., and Bigg, E. K.: Urediospores of rust fungi are ice nucleation active at $>-10^{\circ} \mathrm{C}$ and harbor ice nucleation active bacteria, Atmos. Chem. Phys., 13, 4223-4233, doi:10.5194/acp-13-4223-2013, 2013.

Mugnano, J. A., Lee, R. E., and Taylor, R. T.: Fat body cells and calcium phosphate spherules induce ice nucleation in the freezetolerant larvae of the gall fly Eurosta solidaginis (Diptera, Tephritidae), J. Exp. Biol., 199, 465-471, 1996.

Murase, N., Ruike, M., Matsunaga, N., Hayakawa, M., Kaneko, Y., and Ono, Y.: Spider silk has an ice nucleation activity, Naturwissenschaften, 88, 117-118, 2001.

Murray, B. J., Wilson, T. W., Dobbie, S., Cui, Z., Al-Jumur, S. M. R. K., Möhler, O., Schnaiter, M., Wagner, R., Benz, S., Niemand, M., Saathoff, H., Ebert, V., Wagner, S., and Kärcher B.: Heterogeneous nucleation of ice particles on glassy aerosols under cirrus conditions, Nat. Geosci., 3, 233-237, doi:10.1038/ngeo817, 2010.

Nemecek-Marshall, M., LaDuca, R., and Fall, R.: High-level expression of ice nuclei in a Pseudomonas syringae strain is induced by nutrient limitation and low temperature, J. Bacteriol., 175, 4062-4070, 1993.

Neven, L. G., Duman, J. G., Low, M. G., Sehl, L. C., and Castellino, F. J.: Purification and characterization of an insect hemolymph lipoprotein ice nucleator: evidence for the importance of phosphatidylinositol and apolipoprotein in the ice nucleator activity, J. Comp. Physiol. B, 159, 71-82, 1989.

Niedermeier, D., Shaw, R. A., Hartmann, S., Wex, H., Clauss, T., Voigtländer, J., and Stratmann, F.: Heterogeneous ice nucleation: exploring the transition from stochastic to singular freezing behavior, Atmos. Chem. Phys., 11, 8767-8775, doi:10.5194/acp11-8767-2011, 2011.

Niedermeier, D., Ervens, B., Clauss, T., Voigtländer, J., Wex, H., Hartmann, S., and Stratmann, F.: A computationally efficient description of heterogeneous freezing: A simplified version of the Soccer ball model, Geophys. Res. Lett., 41, 736-741, 2014.

Obata, H., Saeki, Y., Tanishita, J., Tokuyama, T., Hori, H., and Higashi, Y.: Identification of an ice-nucleating bacterium KUIN1 as Pseudomonas fluorescens and its ice nucleation properties, Agric. Biol. Chem., 51, 1761-1766, 1987.

Obata, H., Takinami, K., Tanishita, J., Hasegawa, Y., Kawate, S., Tokutama, T., and Ueno, T.: Identification of a new icenucleating bacterium and its ice nucleation properties, Agric. Biol. Chem. 53, 725-730, 1990a.

Obata, H., Takeuchi, S., and Tokuyama, T.: Release of cell-free ice nuclei from Pseudomonas viridiflava with a Triton X-100/EDTA system and their ice nucleation properties, J. Ferment. Bioengineer., 70, 308-312, $1990 \mathrm{~b}$.

Obata, H., Tanaka, T., Kawahara, H., and Tokuyama, T: Properties of cell-free ice nuclei from ice nucleation-active Pseudomonas fluorescens KUIN-1, J. Ferment. Bioengineer., 76, 19-24, 1993.
Ogawa, S., Koga, M., and Osanai, S.: Anomalous ice nucleation behavior in aqueous polyvinyl alcohol solutions, Chem. Phys. Lett., 480, 86-89, 2009.

Olsen, T. M. and Duman, J. G.: Maintenance of the supercooled state in overwintering pyrochroid beetle larvae, Dendroides canadensis: role of hemolymph ice nucleators and antifreeze proteins, J. Comp. Physiol. B, 167, 105-113, 1997.

Osborne, T. B.: Die Pflanzenproteine, Ergebnisse der Physiologie, 10, 47-215, (in German), 1910

O’Sullivan, D., Murray, B. J., Ross, J. F., Whale, T. F., Price, H. C., Atkinson, J. D., Umo, N. S., and Webb, M. E.: The relevance of nanoscale biological fragments for ice nucleation in clouds, Scientific Reports, 5, 8082, doi:10.1038/srep08082, 2015.

Phelps, P., Giddings, T. H., Prochoda, M., and Fall, R.: Release of cell-free ice nuclei by Erwinia herbicola, J. Bacteriol., 167, 496502, 1986.

Pooley, L. and Brown, T. A.: Preparation of active cell-free ice nuclei from Pseudomonas syringae, P. Roy. Soc. Lond. B, 24, 112 115, 1990.

Popovitz-Biro, R., Wang, J. L., Majewski, J., Shavit, E., Leiserowitz, L., and Lahav, M.: Induced freezing of supercooled water into ice by self-assembled crystalline monolayers of amphiphilic alcohols at the air-water interface, J. Am. Chem. Soc., 116, 1179-1191, 1994.

Pouleur, S., Richard, C., Martin, J. G., and Antoun, H.: Ice nucleation activity in Fusarium acuminatum and Fusarium avenaceum, Appl. Environ. Microbiol., 58, 2960-2964, 1992.

Prenni, A. J., Petters, M. D., Faulhaber, A., Carrico, C. M., Ziemann, P. J., Kreidenweis, S. M., and DeMott, P. J.: Heterogeneous ice nucleation measurements of secondary organic aerosol generated from ozonolysis of alkenes, Geophys. Res. Lett., 36, L06808, doi:10.1029/2008GL036957, 2009.

Pummer, B. G., Bauer, H., Bernardi, J., Bleicher, S., and Grothe, H.: Suspendable macromolecules are responsible for ice nucleation activity of birch and conifer pollen, Atmos. Chem. Phys., 12, 2541-2550, doi:10.5194/acp-12-2541-2012, 2012.

Pummer, B. G., Atanasova, L., Bauer, H., Bernardi, J., Druzhinina, I. S., Fröhlich-Nowoisky, J., and Grothe, H.: Spores of many common airborne fungi reveal no ice nucleation activity in oil immersion freezing experiments, Biogeosciences, 10, 80838091, doi:10.5194/bg-10-8083-2013, 2013a.

Pummer, B. G., Bauer, H., Bernardi, J., Chazallon, B., Facq, S., Lendl, B., Whitmore, K., and Grothe, H.: Chemistry and morphology of dried-up pollen suspension residues, J. Raman Spectrosc., 44, 1654-1658, doi:10.1002/jrs.4395, 2013 b.

Richard, C., Martin, J. G., and Pouleur, S.: Ice nucleation activity identified in some pythopathogenic Fusarium species, Phytoprotection, 77, 83-92, 1996.

Rogers, J. S., Stall, R. E., and Burke, M. J.: Low-temperature conditioning of the ice nucleation active bacterium, Erwinia herbicola, Cryobiol., 24, 270-279, 1987.

Santl-Temkiv, T., Sahyoun, M., Finster, K., Hartmann, S., Augustin, S., Stratmann, F., Wex, H., Clauss, T., Nilsen N. W., Sörensen, J. H., Korsholm, U. S., Wick, L. Y., and Karlson, U. G.: Characterization of airborne ice-nucleation-active bacteria and bacterial fragments, Atmos. Environ., 109, 105-117, doi:10.1016/j.atmosenv.2015.02.060, 2015. 
Sattler, B., Puxbaum, H., and Psenner, R.: Bacterial growth in supercooled cloud droplets, Geophys. Res. Lett., 28, 239-242, doi:10.1029/2000GL011684, 2001.

Schäppi, G. F., Suphioglu, C., Taylor, P. E., and Knox, R. B.: Concentrations of the major birch tree allergen Betv1 in pollen and respirable fine particles in the atmosphere, J. Allerg. Clin. Immunol., 100, 656-661, 1997.

Schill, G. P., De Haan, D. O., and Tolbert, M. A.: Heterogeneous ice nucleation on simulated secondary organic aerosol, Environ. Sci. Technol., 48, 1675-1682, doi:10.1021/es4046428, 2014.

Schmid, D., Pridmore, D., Capitani, G., Battistutta, R., Neeser, J. R., and Jann, A.: Molecular organization of the ice nucleation protein InaV from Pseudomonas syringae, FEBS Lett., 414, 590594, 1997.

Solomon, W. R., Burge, H. A., and Muilenberg, M. L.: Allergen carriage by atmospheric aerosol. I. Ragweed pollen determinants in smaller micronic fractions, J. Allerg. Clin. Immunol.,72, 443447, 1983

Stakman, E. and Christensen, C. M.: Aerobiology in relation to plant disease, Botan. Rev., 12, 205-253, 1946.

Tsumuki, H. and Konno, H.: Ice nuclei produced by Fusarium sp. isolated from the gut of the rice stem borer, Chilo suppressalis Walker (Lepidoptera: Pyralidae), Biosci. Biotech. Biochem., 58, 578-579, 1994.

Tsumuki, H., Yanai, H., and Aoki, T.: Identification of icenucleating active fungus isolated from the gut of the rice stem borer, Chilo suppressalis Walker (Lepidoptera: Pyralidae) and a search for ice-nucleating active Fusarium species, Ann. Phytopathol. Soc. Jpn., 61, 334-339, 1995.

Turner, M. A., Arellano, F., and Kozloff, L. M.: Components of ice nucleation structures of bacteria, J. Bacteriol., 173, 6515-6527, 1991.

Vaitilingom, M., Attard, E., Gaiani, N., Sancelme, M., Deguillaume, L., Flossmann, A. I., Amato, P., and Delort, A.-M.: Long-term features of cloud microbiology at the puy de Dôme (France), Atmos. Environ., 56, 88-100, 2012.

Vali, G.: Quantitative evaluation of experimental results on the heterogeneous freezing nucleation of supercooled liquids, J. Atmos. Sci., 28, 402-409, 1971.

van Eaton, A. R., Harper, M. A., and Wilson, C. J. N.: High-flying diatoms: Widespread dispersal of microorganisms in an explosive volcanic eruption, Geology, 41, 1187-1190, doi:10.1130/G34829.1, 2013

von Blohn, N., Mitra, S. K., Diehl, K., and Borrman, S.: The ice nucleating ability of pollen. Part III: New laboratory studies in immersion and contact freezing modes including more pollen types, Atmos. Res., 78, 182-189, 2005.

Wagner, R., Möhler, O., Saathoff, H., Schnaiter, M., and Leisner, T.: New cloud chamber experiments on the heterogeneous ice nucleation ability of oxalic acid in the immersion mode, Atmos. Chem. Phys., 11, 2083-2110, doi:10.5194/acp-11-2083-2011, 2011.
Wang, B. and Knopf, D. A.: Heterogeneous ice nucleation on particles composed of humic-like substances impacted by $\mathrm{O}_{3}$, J. Geophys. Res., 116, D03205, doi:10.1029/2010JD014964, 2011.

Wang, B., Lambe, A. T., Massoli, P., Onasch, T. B., Davidovits, P., Worsnop, D. R., and Knopf, D. A.: The deposition ice nucleation and immersion freezing potential of amorphous secondary organic aerosol: Pathways for ice and mixed-phase cloud formation, J. Geophys. Res., 117, D16209, doi:10.1029/2012JD018063, 2012.

Warren, G. and Wolber, P.: Molecular aspects of microbial ice nucleation, Mol. Microbiol., 5, 239-243, 1991.

Welti, A., Lüönd, F., Kanji, Z. A., Stetzer, O., and Lohmann, U.: Time dependence of immersion freezing: an experimental study on size selected kaolinite particles, Atmos. Chem. Phys., 12, 9893-9907, doi:10.5194/acp-12-9893-2012, 2012.

Wilson, T. W., Murray, B. J., Wagner, R., Möhler, O., Saathoff, H., Schnaiter, M., Skrotzki, J., Price, H. C., Malkin, T. L., Dobbie, S., and Al-Jumur, S. M. R. K.: Glassy aerosols with a range of compositions nucleate ice heterogeneously at cirrus temperatures, Atmos. Chem. Phys., 12, 8611-8632, doi:10.5194/acp-128611-2012, 2012.

Wolanczyk, J. P., Storey, K. B., and Baust, J. G.: Ice nucleating activity in the blood of the freeze-tolerant frog, Rana sylvatica, Cryobiol., 27, 328-335, 1990.

Xu, H., Griffith, M., Patten, C. L., and Glick, B. R.: Isolation and characterization of an antifreeze protein with ice nucleation activity from the plant growth promoting rhizobacterium Pseudomonas putida GR12-2, Can. J. Microbiol., 44, 64-73, doi:10.1139/w97-126, 1998.

Yttri, K. E., Dye, C., and Kiss, G.: Ambient aerosol concentrations of sugars and sugar-alcohols at four different sites in Norway, Atmos. Chem. Phys., 7, 4267-4279, doi:10.5194/acp-7-4267-2007, 2007.

Zachariassen, K. E. and Kristiansen, E.: Ice nucleation and antinucleation in nature, Cryobiol., 41, 257-279, 2000.

Zobrist, B., Marcolli, C., Koop, T., Luo, B. P., Murphy, D. M., Lohmann, U., Zardini, A. A., Krieger, U. K., Corti, T., Cziczo, D. J., Fueglistaler, S., Hudson, P. K., Thomson, D. S., and Peter, T.: Oxalic acid as a heterogeneous ice nucleus in the upper troposphere and its indirect aerosol effect, Atmos. Chem. Phys., 6, 3115-3129, doi:10.5194/acp-6-3115-2006, 2006.

Zobrist, B., Koop, T., Luo, B. P., Marcolli, C., and Peter, T.: Heterogeneous ice nucleation rate coefficient of water droplets coated by a nonadecanol monolayer, J. Phys. Chem. C, 111, 2149-2155, 2007.

Zuberi, B., Bertram, A. K., Koop, T., Molina, L. T. and Molina, M. J.: Heterogeneous Freezing of Aqueous Particles Induced by Crystallized $\left(\mathrm{NH}_{4}\right)_{2} \mathrm{SO}_{4}$, Ice, and Letovicite, J. Phys. Chem. A, 105, 6458-6464, doi:10.1021/jp010094e, 2001. 